\title{
Dairy Farmers Perception on Cooperatives in East Java, Indonesia
}

\author{
Hery Toiba $^{1^{*}}$, Rachman Hartono ${ }^{1}$, Dwi Retnoningsih ${ }^{1}$, Moh. Shadiqur Rahman ${ }^{2}$ \\ ${ }^{1}$ Agricultural Socio-economic Department, Brawijaya University, Jl. Veteran Malang, 65145, Indonesia \\ ${ }^{2}$ Department of Tropical Agriculture and International Cooperation, National Pingtung University of \\ Science and Technology, Pingtung 912, Taiwan
}

Received: 10 December 2019; Revised: 8 October 2021; Accepted: 18 October 2021

\begin{abstract}
Although past studies have shown that cooperatives can improve the welfare of rural communities. However, many farmers did not aware about the cooperative advantages. This begs a question as to whether cooperatives really contribute to the rural incomes and economies. This study aims to assess farmers' perception on cooperative membership and how members have adopted innovative technologies. Data were obtained from a survey with 300 dairy farmers in Malang and Batu, East Java. The data were examined using a descriptive analysis. The results showed that farmers who do not join any cooperatives perceive that the institution is not able to determine the quality of their milk produce. Meanwhile, farmers who are members of a cooperative perceive that the institution can maintain stability of milk produce's sales prices. This implies that education about cooperatives among farmers needs to be improved so that they can objectively view the benefits of cooperative membership and make informed decision in their economic activities.
\end{abstract}

Keywords: cooperatives; dairy farmers; perception

How to cite:

Toiba, H., Hartono, R., Retnoningsih, D., \& Rahman, M. S. (2021). Dairy Farmers Perception on Cooperatives in East Java , Indonesia. HABITAT, 32(3), 113-118. https://doi.org/10.21776/ub.habitat.2021.032.3.13

\section{Introduction}

Fluctuating sales prices of agricultural produce and limited market access are common problems faced by small farmers in the countryside. Modern cooperatives are seen to provide the solutions (Ahmed \& Mesfin, 2017). They indeed play an important role in improving welfare of smallholders in many developing countries (Ojiagu \& Onugu, 2015; Wang, Cheng, Lee, Sun, \& Chang, 2019), including farmers. Cooperatives can facilitate various economic activities and benefit the members by providing better bargaining power, increasing access to inputs, credit and market, and boosting technology adoption (Bijman, 2018; Sudan, 2019; Wossen et al., 2017). In dairy agribusiness sector, cooperatives can reduce transaction costs and facilitate market integration, especially for smallholders (Chagwiza, Muradian, \& Ruben, 2016). According to (Mojo, Fischer, \& Degefa,

*) Correspondence Author.

E-mail: htoiba@ub.ac.id
2017), farmers who are cooperative members tend to have higher income and more assets than those who are not. Research conducted by (Debela, Diriba, \& Bekele, 2018) in Ethiopia shows that being a cooperative member has a positive impact on productivity, savings and market surplus in farmer households. (Bayan, 2018) also argues that cooperative membership can contribute to the increase in dairy produce yields, as well as farmer households' health and food security. They will also have easier access to credit (Nwankwo, Ogbodo, \& Onwuchekwa, 2019).

Although the role of cooperatives in improving welfare of dairy farm smallholders has been demonstrated in past research, income gaps between rural and urban households remain large. It begs a question as to whether cooperatives actually contribute to the local economies because they are mostly located in the countryside. Considering this, it is important to know how farmers view the roles of cooperatives in their economic activities. Therefore, the current study aims to examine farmers' 
perceptions on cooperative membership and how innovative technologies are adopted among them.

\section{Theoretical Underpinning}

This paper investigates the farmers' perception of dairy farm cooperative. Cooperative is known as an essential institution that can help farmers to achieve their livelihood need by providing technology innovation, and marketing opportunities (Ma and Abdulai, 2016). The advantages of cooperative on agricultural sectors have been observed well in the literature, it is likely to improve the warfare condition (Ma and Abdulai, 2016), farming performance, (Ma et al., 2018; Ma et al., 2021; Ankrah Twumasi et al., 2021), technology innovation (Zhang et al., 2020), and market access (Shiferaw et al., 2011). For instance, using cross-sectional data from 418 smallholders farmers in China, Ma and Abdulai (2016) reposted that cooperative membership significantly increased farmers' welfare conditions throughout improving the agricultural productivity, net return, and household income. A study conducted by (Ma et al., 2021) investigated the impact of cooperative membership on farming performance, which was measured by return on investment (ROI)m and profit margin. The results indicated that farmers who participle in cooperative have a higher farm performance than farmers who had not. Similarly, using technical efficiency measurement to assess the role of cooperative membership on farming performance, Ma et al. (2018) pointed out that cooperative significantly increased farm performance. Furthermore, cooperatives also provide technology innovation to support agriculture production. Zhang et al. (2019) found a positive association between cooperative membership and technology adoption for smallholder farmers. Particularly, cooperatives deserve agricultural-related technology innovation that can easily be accessed by the members. Interestingly, cooperatives also provide agriculture market access, such as access to input and output. Although the literature have been pointed out well regarding the important role of an agricultural cooperative. However, the farmers' awareness and intention to be the cooperative members are remain low. Therefore, investigating the farmers' perception on cooperative is essential to be the start-up in promoting the agricultural cooperative.

\section{Research Method}

The research location was determined by using multi-stages sampling method. First, the province and district-East Java and Malang district - were chosen with the consideration that they have high achievements and participation of farmers in dairy cooperatives. Second, the subdistrict sample locations were selected randomly based on the information obtained from various sources such as government agencies (Cooperatives Office) and secondary data from the statistics bureau (BPS). From the two subdistricts, two villages were randomly selected so that a total of four villages became the research final locations. Simple random sampling was then used to determine the research respondents. From a list of all dairy farmers in each of the four villages, a research sampling frame was determined. Then, 75 respondent farmers were selected from each village so that a total of 300 farmer respondents participated in the study. Descriptive analysis was used to examine the data.

\section{Results and Discussion}

\subsection{Respondents' Profiles}

Table 1. Farmers profiles

\begin{tabular}{lll}
\hline The number of family members & Total & Percentage (\%) \\
\hline 0-2 people & 26 & $9 \%$ \\
3-4 people & 230 & $76 \%$ \\
5-6 people & 44 & $15 \%$ \\
\hline Age & 43 & $14 \%$ \\
\hline 21-30 years & 91 & $30 \%$ \\
31-40 years & 95 & $33 \%$ \\
41-50 years & 46 & $15 \%$ \\
51-60 years & 25 & $8 \%$ \\
>60 years & \multicolumn{2}{c}{$3 \%$} \\
Highest Education Level & 9 & $3 \%$ \\
\hline Not completing primary school & Available online at HABITAT website: http://www.habitat.ub.ac.id \\
\multicolumn{2}{c}{ ISSN: 0853-5167 (p); 2338-2007 (e) }
\end{tabular}


Graduated from primary school

Graduated from junior high school

Graduated from senior high school

Graduated from university

191

60

36

4

\section{Dairy Farming Experience}

$0-10$ years

11-20 years

21-30 years

31-40 years

41-50 years

$>50$ years

\section{2}

120

45

23

16

4
$64 \%$

$20 \%$

$12 \%$

$1 \%$
Respondents in this study were dairy farmers in Jabung Village, Malang Regency; and Pesanggrahan Village, Batu Regency. Based on the table above, as many as 230 respondents have 3-4 family members with a percentage of $76 \%$ of the total sample. As many as 26 respondents have 0-2 the number of family members with a percentage of $9 \%$ of the total sample. Most of the farmers were 41-50 years old with a percentage of $33 \%$ of the total sample, while respondents aged more than 60 years only makes up $8 \%$ of the total sample. The highest education level of the majority was elementary school with a total of 191 people or $64 \%$ of the total sample. Only four people or $1 \%$ of the total respondents have obtained a bachelor's degree. The majority of respondents have 11-20 years of experience in raising livestock with a percentage of $40 \%$, while a small number of respondents have experience of raising livestock for more than 50 years or $1 \%$ of the total respondents.

\subsection{Reasons for not joining a cooperative}

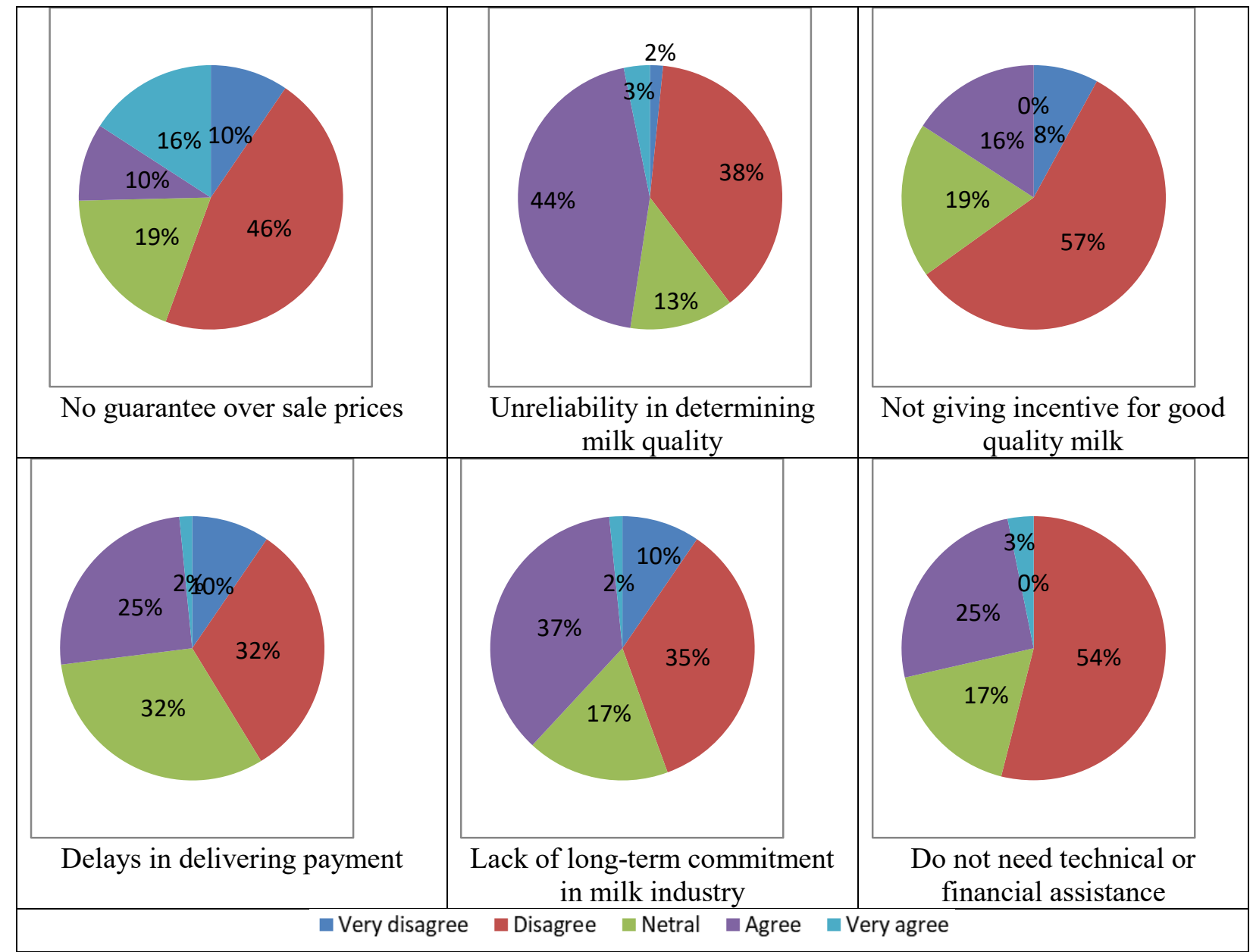

Figure 1. Reasons for not joining a cooperative

Available online at HABITAT website: http://www.habitat.ub.ac.id ISSN: 0853-5167 (p); 2338-2007 (e) 
Not all respondents in this study are members of cooperatives. Of the 300 respondents, 237 are members of cooperatives and 63 farmers are not. Figure 1 shows the reasons why farmers are not members of cooperatives. Most of them conveyed that the reason they are not members of cooperatives is because they perceive cooperative unreliable in determining the quality of milk produced. Most of them also believe that cooperatives are not highly committed in buying and selling milk. This means that, in order to attract the interest of dairy farmers, cooperatives need to build trust with farmers. They also need to build their image and show their commitment so that farmers will trust them with the quality of milk assessment.

\subsection{Motivations to join a cooperative}

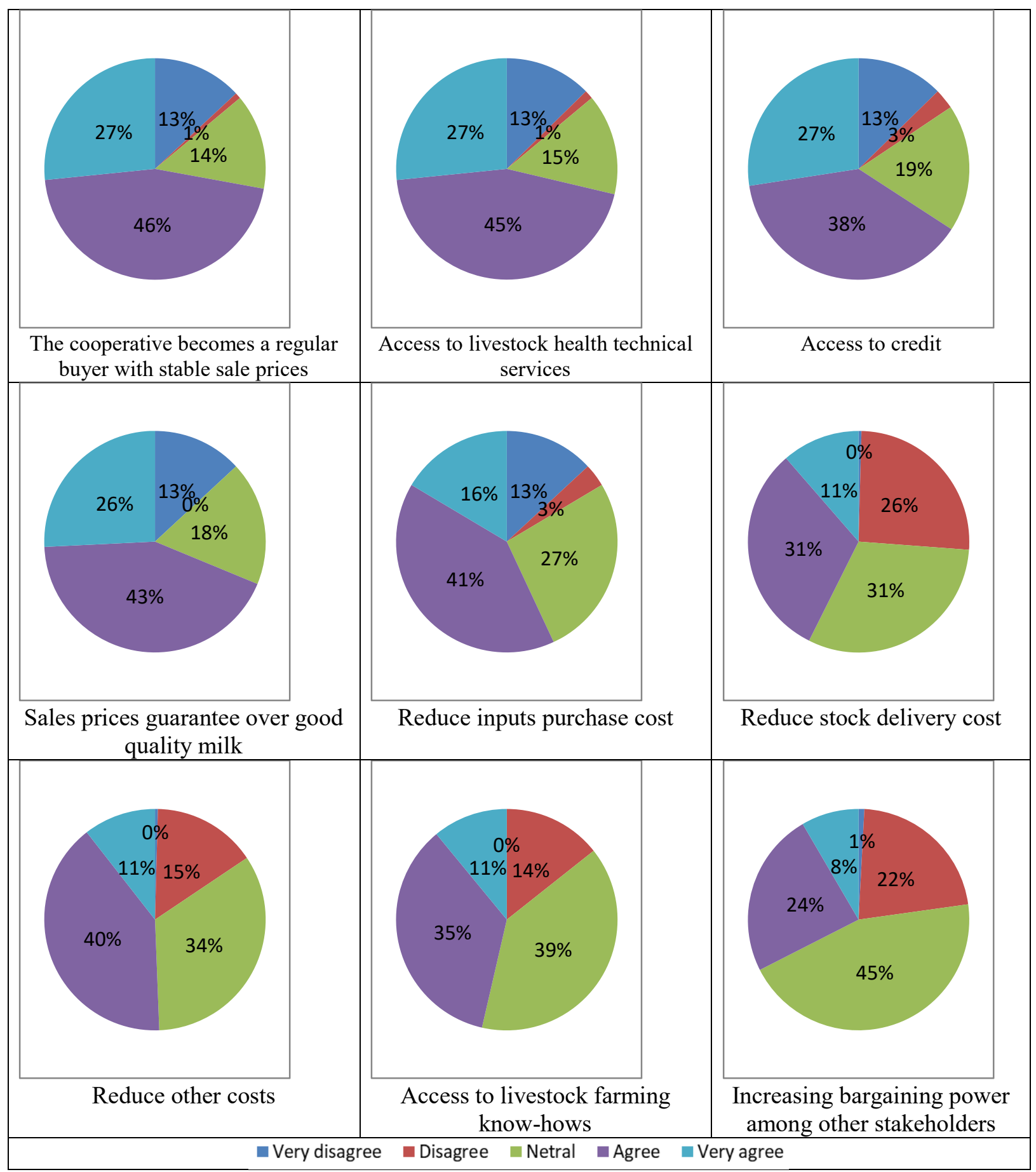

Figure 2. Motivations to join a cooperative 
As previously explained, most of the samples in this study are farmers who are members of cooperatives. Figure 2 shows the reasons why they become members of cooperatives. The survey results show that most farmers agree that cooperative membership allows them to sell their milk produce at a stable price. They also agree that the cooperative is able to provide access to animal health services and credit, guarantee prices based on milk quality and reduce the cost of inputs. This shows that becoming a member of a cooperative has benefitted production activities and farmers' welfare in general.

\subsection{Adoption of milk production and processing innovative technologies}

Figure 3. shows the adoption of milk technologies. The use of artificial insemination is commonplace among dairy farmers; $99 \%$ of farmers have used this innovation. Artificial insemination is considered useful in giving better results and overcome the problem of lack of superior males. Meanwhile, to produce good quality milk, farmers sterilise the nipples before milking. However, no farmer does their own milk processing. They directly sell unprocessed milk to cooperatives (if they are members) and traders (if they are not members). This is an area that could be improved because processing milk will allow farmers to earn more. The reasons why farmers directly sell their produce without processing it is because of the lack of knowledge about milk processing. They also do not have the facilities and infrastructure. Moreover, cooperatives only purchase unprocessed milk. production and processing innovative

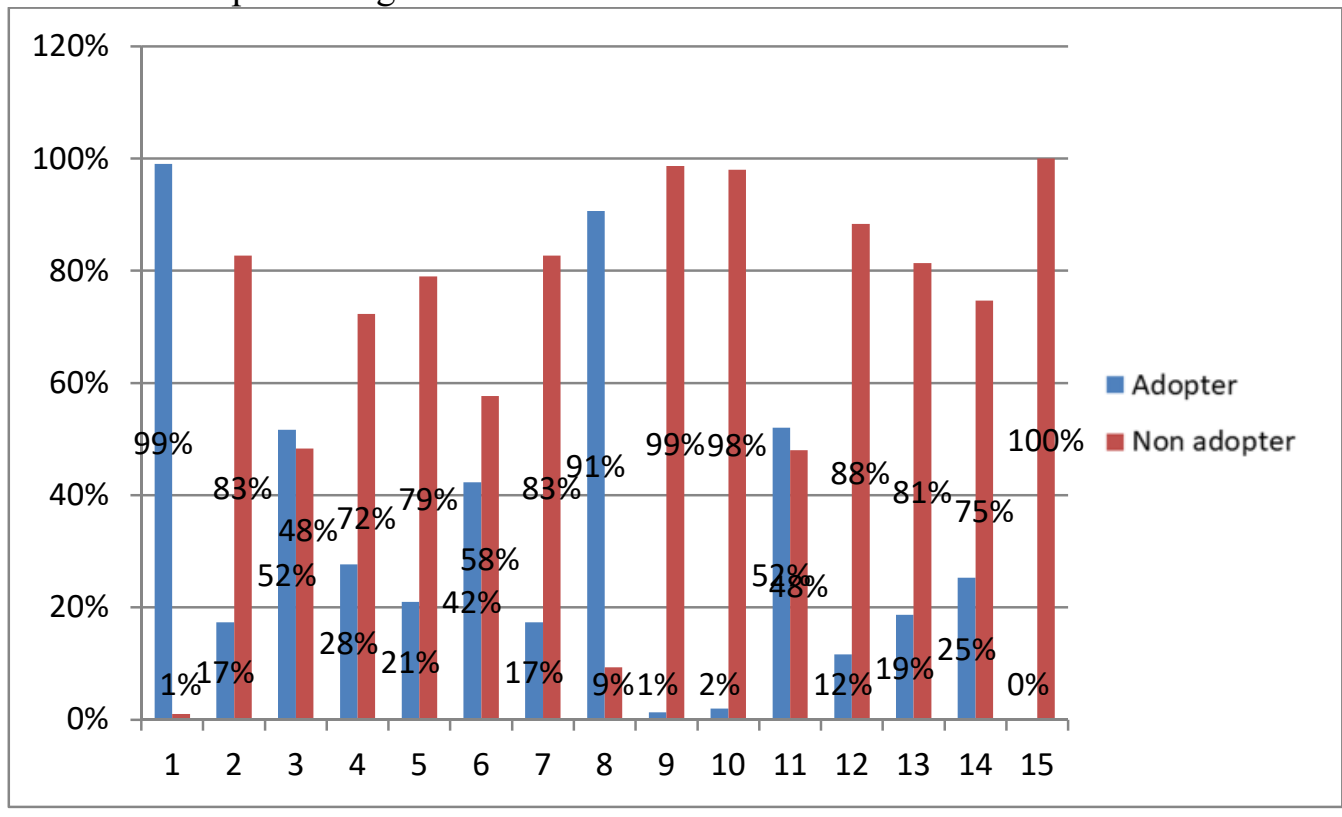

Note

Figure 3. Adoption of milk production and milk processing innovative technologies

$1=$ The use of artificial insemination

$2=$ The use of detergent for the milking tools

$3=$ The use of rubber floor for the shed

4 = The use of milking tools made of stainless steel

5 = Mastitis test (cow milk inflammation)

$6=$ Strict hygiene in the milking process to reduce the number of microbes (TPC)

7 = Plant new varieties' seedlings

8 = Sterilise the nipples properly before milking

$9=$ The use of legumes feed

$10=$ Milk pasteurisation

$11=$ The use of high protein concentrate

$12=$ The use of automated milking machine

$13=$ The use of Feed Block Supplement (FBS)

$14=$ The use of biogas unit

$15=$ The application of milk processing 


\section{Conclusion}

From the results of the study, it can be concluded that the reasons why farmers are not members of cooperatives are mostly because they tend to have a negative perception of cooperatives. Meanwhile, farmers who become members of cooperatives perceive cooperatives more positively. In terms of technological adoption, it is still limited to the production of fresh milk and has not covered milk processing.

\section{References}

Ahmed, M. H., \& Mesfin, H. M. (2017). The impact of agricultural cooperatives membership on the wellbeing of smallholder farmers: empirical evidence from eastern Ethiopia. Agricultural and Food Economics, 5(1), 6.

Ankrah Twumasi M, Jiang Y, Addai B, et al. (2021) The Impact of Cooperative Membership on Fish Farm Households' Income: The Case of Ghana. Sustainability 13: 1059 .

Bayan, B. (2018). Impacts of dairy cooperatives in smallholder dairy production systems: a case study in Assam. Agricultural Economics Research Review, 31(1), 8794.

Bijman, J. (2018). Exploring the sustainability of the cooperative model in dairy: The case of The Netherlands. Sustainability, 10(7), 2498.

Chagwiza, C., Muradian, R., \& Ruben, R. (2016). Cooperative membership and dairy performance among smallholders in Ethiopia. Food policy, 59, 165-173.

Debela, M., Diriba, S., \& Bekele, H. (2018). Impact Of Cooperatives Membership On Economy In Eastern Oromia: The Case Of Haramaya Agricultural Farmers'cooperative Union (HAFCU). Annals of Public and Cooperative Economics, 89(2), 361-376.

Ma W and Abdulai A. (2016) Does cooperative membership improve household welfare? Evidence from apple farmers in China. Food policy 58: 94-102.

Ma W, Renwick A, Yuan P, et al. (2018) Agricultural cooperative membership and technical efficiency of apple farmers in
China: An analysis accounting for selectivity bias. Food policy 81: 122-132.

Ma W, Zheng H, Zhu Y, et al. (2021) Effects of cooperative membership on financial performance of banana farmers in China: a heterogeneous analysis. Annals of Public and Cooperative Economics.

Mojo, D., Fischer, C., \& Degefa, T. (2017). The determinants and economic impacts of membership in coffee farmer cooperatives: recent evidence from rural Ethiopia. Journal of Rural Studies, 50, 84-94.

Nwankwo, F. O., Ogbodo, O. C., \& Onwuchekwa, F. C. (2019). Agricultural Credit and Farm Output of Cooperative Members in Anambra State, Nigeria.

Ojiagu, N., \& Onugu, C. (2015). Uchenna.(2015). Effects of membership of cooperative organizations and determinants on farmer-members' income in rural Anambra State, Nigeria. International Journal of Scientific \& Technology Research, 4(8), 28-35.

Shiferaw B, Hellin J and Muricho G. (2011) Improving market access and agricultural productivity growth in Africa: what role for producer organizations and collective action institutions? Food Security 3: 475489.

Sudan, F. K. (2019). Role of Dairy Cooperatives in Achieving the Economic Dimension of the SDGs.

Wang, B., Cheng, P.-Y., Lee, B., Sun, L.-C., \& Chang, H.-H. (2019). Does Participation in Agricultural Cooperatives Affect Farm Sustainability? Empirical Evidence from Taiwan. Sustainability, 11(18), 4987.

Wossen, T., Abdoulaye, T., Alene, A., Haile, M. G., Feleke, S., Olanrewaju, A., \& Manyong, V. (2017). Impacts of extension access and cooperative membership on technology adoption and household welfare. Journal of Rural Studies, 54, 223233.

Zhang S, Sun Z, Ma W, et al. (2020) The effect of cooperative membership on agricultural technology adoption in Sichuan, China. China Economic Review 62: 101334. 